\title{
LEADERSHIP'S ACTIVATION OF TEAM COHESION AS A STRATEgIC ASSET: AN EMPIRICAL SIMULATION
}

\author{
Michael D. Michalisin \\ Steven J. Karau \\ Southern Illinois University Carbondale \\ Carbondale, IL \\ Charnchai Tangpong \\ North Dakota State University \\ Fargo, ND
}

\begin{abstract}
The current study examined the linkage between leadership, team cohesion, and superior performance using group process and performance data collected from a strategic management simulation conducted over a four-month period. Results showed that organizational leadership was not directly associated with superior performance (SP) of simulated firms. However, leadership was significantly associated with team cohesion, which in turn was significantly associated with $S P$, suggesting that leadership may strengthen performance indirectly by effectuating key group process mechanisms. Consistent with the Resource Based View of the firm, these findings suggest that leader behavior, through its positive impact on the development of team cohesion, can yield superior performance.
\end{abstract}

\section{Introduction}

Organizational researchers have long studied the effects of organizational leadership on firm performance, producing a rich array of theories and empirical findings (Bass, 1990; House \& Podsakoff, 1995; Yukl, 1998). These theories and studies have revealed that the relationship between leadership behavior and specific performance outcomes is complex, and that the specific behaviors that are effective often depends on a variety of variables, including situational factors and follower characteristics (Blake \& Mouton, 1985; Hersey \& Blanchard, 1988; House, 1971). Although the context-dependency of effective leader behavior may make consistent, direct relationships with firm performance unlikely, it is possible that leadership might still serve to activate group process variables and other intangible factors that may have a more stable, direct, and significant relationship with ongoing firm performance. Thus, consistent with the Resource Based View of the firm (Dierickx \& Cool, 1989), leadership could serve to activate resources and core processes crucial to organizational functioning that could, in turn, have a potent effect on firm performance. One such resource could be the cohesion of 
the top management team (TMT). Indeed, a large number of studies have shown that cohesion often has a strong relationship with group performance (Mullen \& Copper, 1994). TMT cohesion may also have the potential to operate as an intangible strategic asset by helping the TMT reach consensus on strategic direction and organizational controls, as well as by facilitating communication and commitment to shared organizational goals (Smith, Smith, Olian \& Sims, 1994).

The current research examines the nature of the relationship between leadership and superior performance. Does leadership directly affect performance? Or does leadership indirectly influence performance through group process resources, such as team cohesion? The major purpose of the study was to examine the possibility that leadership has an indirect effect on superior performance that operates via cohesion. Specifically, we sought to empirically examine the following relationships: (a) the relationship between leadership and the superior performance of simulated firms, (b) the relationship between team cohesion and superior performance, and (c) the relationship between leadership and team cohesion.

\section{Leadership and Firm Performance}

Existing research on the relationship between leadership and firm performance has produced mixed results (Bass, 1990; Lieberson \& O'Connor, 1972; Salancik \& Pfeffer, 1977; Thomas, 1988). This has divided scholars in their contention (Channon, 1979; Hambrick \& Mason, 1984; Waldman, Ramirez, House \& Puranam, 2001; Weiner \& Mahoney, 1981) or opposition, that leadership, in and of itself, has a direct impact on firm performance (Cyert \& March, 1963; Hannan \& Freeman, 1977; Khurana, 2002; Lieberson \& O'Connor, 1972; Salancik \& Pfeffer, 1977). Some have argued that the inconsistent findings are due to methodological differences, (Thomas, 1988; Weiner \& Mahoncy, 1981), whereas others propose that further empirical studies should focus on when and how leadership affects firm performance (Day \& Lord, 1988). The lack of consistency in prior empirical findings suggests that consistent, direct relationships between leadership behavior and firm performance may be unlikely to emerge.

Prior research and theory on both leadership style and contingency approaches to leadership provide additional support for our reasoning that the relationship between leadership and firm performance is more likely to be indirect, rather than direct. With regard to leadership style research, the classic research programs conducted by scholars at Ohio State (Stodgill \& Coons, 1957) and Michigan (Katz \& Kahn, 1978) converged on the identification of two primary leadership styles consisting of task and interpersonal aspects (initially called initiating structure and consideration), but no single leadership style appeared to be appropriate to all situations. Similarly, research on autocratic, democratic, and participative leadership (Foels, Driskell, Mullen \& Salas, 2000), as well as on transactional, transformational, and charismatic leadership (Jung \& Avolio, 1999; Howell \& Shamir, 2005) has also found than no single leadership style is universally effective. Although Blake and Mouton's (1985) "high-high" notion that effective 
leaders must be attentive to both task and social aspects of the work setting resonated with many scholars, empirical results generally found that no single style of leadership was effective across all contexts (Bass, 1990).

Due to the difficulty in identifying universally effective leadership styles, a host of contingency theories were developed to try to explain what behaviors are effective in what specific contexts. For example, situational leadership theory (Hersey \& Blanchard, 1988), path-goal theory (House, 1971), and the normative decision model (Vroom \& Yetton, 1973) all created different classifications of leader behaviors that could lead to either positive or negative performance, depending on workplace variables, follower characteristics, and individual and team processes. Thus, all of these views suggest that the degree of fit between leader behavior and work context should enhance performance via specific individual and group-level processes. However, these views disagree on what specific leadership behaviors impact performance under different conditions. For example, the leadership match theory focuses on task structure and managerial position power, Path-Goal theory implicates subordinate perceptions regarding expectancy and instrumentality of effort, and the normative model focuses on characteristics of decisions that may require more or less input from subordinates. Interestingly, despite disagreements about the conditions under which specific leader behaviors are optimally effective, all of these views converge to highlight the importance that task-focused and socially-oriented leadership behaviors play in supporting and enhancing processes key to organizational performance, such as worker motivation and team dynamics. Thus, although these theories disagree on when specific leadership styles are most effective, they agree that leadership is likely to have an impact on organizational processes that may be more directly linked with performance. Taken as a whole, the prior leadership literature depicts a complex relationship between leaders' task and social behaviors and firm performance and suggests that neither task nor social behavior is likely to have a direct effect on the firm's ability to produce sustainable competitive advantage across a range of contexts, as would be evidenced by superior performance over time. Thus, we predicted that leadership would be unlikely to show a significant, direct relationship with the superior performance of the simulated firms used in the current study.

\section{Hypothesis 1: Leadership will have no direct relationship with the per- formance of simulated firms. \\ Hypothesis la: Task leadership will have no direct relationship with the performance of simulated firms. \\ Hypothesis $1 \mathrm{~b}$ : Social leadership will have no direct relationship with the performance of simulated firms.}

Although both task and social leadership may be unlikely to have direct effects on performance that are not heavily context-dependent, they could well have direct effects on team processes that are, in turn, central to performance. One key team process that is often central to performance is cohesion (Mullen \& 
Copper, 1994). Thus, to the extent that task and social leadership contribute to the development and maintenance of team cohesion, leadership may well contribute indirectly to performance via cohesion. We will now address the theoretical and empirical support for the linkages between leadership and team cohesion, as well as between team cohesion and performance, in separate sections.

\section{Leadership and Team Cohesion}

Cohesion is a complex, possibly multidimensional construct that has been defined and operationalized in a variety of ways. However, the majority of theoretical and empirical treatments have emphasized members' attraction to the group and desire to remain in the group (Cartwright, 1968; Hogg, 1992). Consistent with these prior treatments, we defined team cohesion as the degree to which members are attracted to their team and desire to remain in it. We propose that both task and social leadership can contribute to team cohesion, such that leaders can engage in behaviors that are likely to increase members' attraction to the group and desire to continue interacting with the group.

Most of the cohesion literature has focused on performance outcomes rather than on factors that create cohesion (the performance studies are reviewed in the section below entitled Cohesion and Firm Performance). Nevertheless, a number of studies examining a variety of group contexts do converge to suggest that leadership can contribute to cohesion. For example, several studies have found positive relationships between transformational leadership and team cohesion among laboratory groups (Hoyt \& Blascovich, 2003), light infantry platoons (Bass, Jung, Avolio \& Berson, 2003), fire rescue personnel (Pillai \& Williams, 2004), and workgroups in Korean firms (Jung \& Sosik, 2002). Bass et al. (2003) also showed that team cohesion was positively associated with platoon performance. Though these studies did not identify the specific elements of transformational leadership responsible for increased cohesion, Jung and Sosik (2002) reasoned that empowering followers, emphasizing cooperation, and realigning values may have played a role. Rozell and Gunderson (2003) found that leaders who used effective impression management techniques heightened feelings of cohesion within laboratory groups. Within the team sports context, research has found that coaches who attend actively to skill development, motivational communication, and social support of players tend to have more cohesive teams (Gardner, Shields, Bredemeier \& Bostrom, 1996; Turman, 2003). Similarly, literature on team building has emphasized the coaching or facilitation role that leaders can play in building the group's cohesion and commitment to shared goals, in order to make optimal use of group resources (Dyer, 1977; Pritchard, Roth, Jones, Galgay \& Watson, 1988). Finally, a review of 23 studies examining leadership behaviors and associated outcomes in environments designed as analogs for long-duration space flight concluded that effective leaders maintained group harmony and cohesion by attending both to mission-specific task outcomes and to the expertise and personal qualities of crew members (Nicholas \& Penwell, 
1995). Thus, a number of prior studies have documented relationships between leadership and team cohesion, though the specific leader behaviors, team types, tasks, and settings examined have varied widely.

Although research on the specific issue of leadership and team cohesion is limited, research on the broader issue of how cohesion develops does help to identify factors relevant to leadership that may contribute to cohesion. Specifically, it has been found that cohesion is stronger among groups that have a shared social identity (Hogg \& Terry, 2000), common goals (Guthrie \& Hollensbe, 2004; Seashore, 1954), a shared commitment to completing team tasks (Myers, 1962), a belief that teammates are trustworthy (Yalom, 1985), and an awareness of a shared outcome or fate (Brewer \& Kramer, 1986). Thus, it is possible that task leadership could enhance cohesion by keeping group members focused on completing important tasks and attaining valued goals and outcomes.

Research has also shown that cohesion is fostered by demonstrations of liking and respect among teammates (Hoegl \& Gemuenden, 2001; Lott \& Lott, 1961), harmony among group members (Stokes, 1983), lessened social anxiety (Pepitone \& Reichling, 1955) and meaningful, shared social experiences (Darley, Gross \& Martin, 1951; Yalom, 1985). Studies have also found that teams can develop cohesion, in part, by establishing clear behavioral norms and enforcing these norms by rejecting deviant behavior (Feldman, 1984; Williams, 2001). Thus, it is possible that social leadership could enhance cohesion by encouraging respect for team members, maintaining group harmony, fostering positive group experiences and social activities over time, encouraging information sharing among members, and preventing deviant team members from exerting a negative influence on the group.

In summary, prior research on the specific issue of leadership and team cohesion has provided initial evidence that leader behaviors can contribute to cohesion. Research on the more general issue of sources of cohesion provides evidence suggesting that task leadership can contribute to cohesion by keeping the team focused on the work and enhancing shared commitment to completing the work, and that social leadership can contribute to cohesion by maintaining team harmony and good relationships, facilitating meaningful social interaction, and thwarting deviant members' attempts to exert negative influence on the group.

Hypothesis 2: Leadership will be positively associated with cohesion. Hypothesis 2a: Task leadership will be positively associated with cohesion.

Hypothesis 2b: Social leadership will be positively associated with cohesion.

\section{Cohesion and Firm Performance}

A large empirical literature consisting of hundreds of studies has shown that cohesion can enhance the performance of a wide variety of groups and teams, 
including laboratory groups, sports teams, work teams, therapy groups, and organizational groups (Beal, Cohen, Burke \& McLendon, 2003; Hogg, 1992; Mullen \& Copper, 1994). However, nearly all of these studies have studied either non-organizational teams, or teams at lower levels of the organization, and have examined group performance rather than firm performance. A top management team (TMT) is a group of high-level managers responsible for formulating and implementing the firm's strategies. The power to control the direction and performance of the firm probably makes TMT the most important and influential team in the firm (Smith et al., 1994). Thus, among all organizational teams, it is the cohesion of the TMT that is most likely to have an impact on firm performance. Unfortunately, only three studies (Michalisin, Karau \& Tangpong, 2004; Michel \& Hambrick, 1992; Smith et al, 1994) have examined the association between top management team cohesion (or variables highly relevant to TMT cohesion) and firm performance. Specifically, Michalisin et al. (2004) documented a positive association between team cohesion and superior performance. Similarly, Michel and Hambrick (1992) found a positive association between team tenure and firm performance, and Smith et al. (1994) found a positive association between social integration and firm performance. Taken as a whole, the available empirical research provides strong evidence for a relationship between team cohesion and team performance and initial evidence for a relationship between TMT cohesion and firm performance, though the research on the latter topic is clearly in its embryonic stages. In the current research, we examine cohesion within a large sample of teams of students playing the role of the top management team of airline firms in a complex strategic management simulation to draw well-controlled inferences about linkages between leadership, cohesion, and the superior performance of simulated firms. Given the dearth of cohesion and performance studies among practicing TMTs, the use of a well-controlled simulation methodology allows us to contribute insights about phenomena that are typically very hard to access in actual TMTs.

Though the empirical research on TMT cohesion and firm performance is limited, the Resource Based View of the firm (RBV) provides a strong theoretical basis for predicting that this relationship should be significant and positive. According to the RBV, resources are the main drivers of sustainable competitive advantage. The most valuable resources - referred to as strategic assets - are simultaneously valuable, rare, difficult and costly to imitate, and nonsubstitutable (Amit \& Schoemaker, 1993; Barney, 1991). Since its inception (Wernerfelt, 1984), RBV has received considerable attention in the strategy literature, indicating some consensus as to its viability as an alternative explanation of superior industry returns (Mauri \& Michaels, 1998).

According to the RBV, resources are valuable when they allow the firm to take advantage of opportunities and/or neutralize threats in the external environment (Barney, 1991). Given the central role that the TMT plays in implementing offensive and defensive firm strategies (Smith et al., 1994), resources that facilitate TMT performance, such as cohesion, should be highly valuable to the firm. The 
large literature on cohesion and performance cited earlier clearly provides both logical and empirical support for the value of TMT cohesion. In addition a number of studies have documented that cohesion is conducive to effective group processes that are also likely to enhance TMT performance. For example, Ensley, Pearson, and Amason (2002) found that TMT cohesion was positively associated with cognitive conflict (i.e., task-focused conflict that is often essential to making quality decisions) and was negatively associated with affective conflict (i.e., personalized conflict that often detracts from effective team performance). Additional research has shown that cohesion can facilitate effective communication (Lott \& Lott, 1961), coordination of member inputs (Hoegl \& Gemuenden, 2001), and willingness to exert effort on group tasks (Karau \& Williams, 1997). Thus, in relation to RBV logic, the available empirical evidence converges to suggest that TMT cohesion should constitute a highly valuable resource to the firm.

Top management team cohesion (TMTC) also appears to simultaneously possess all of the remaining characteristics of a strategic asset. TMTC is rare, and difficult and costly to imitate for six reasons. First, consensus in the team cohesion literature is that similarity among team members in terms of background, experience, and values promotes cohesion (Hogg, 1992). If true, then TMTC will vary across companies based on the unique composition of each TMT, including differences in TMT size (Jones, George \& Hill, 1998). Second, TMTC develops over time and is affected by interaction and unique historical conditions, making it rare and difficult to imitate (Barney, 1991). Third, TMTC is a socially complex phenomenon reflecting the unique attributes of team members and their attraction to one another and the team (Barney \& McEwing, 1996). Fourth, TMTC is an invisible resource, making it hard for competitors to imitate (Godfrey \& Hill. 1995). Fifth, even if competitors are cognizant of a firm's TMTC, its impact on firm performance is often causally ambiguous (Reed \& DeFillippi, 1990). Sixth, attempting to perfectly replicate another firm's TMTC would probably require hiring their entire TMT. Even if all TMT members agreed to join the competitor, it may be very costly and the team's cohesion could be impacted by the new corporate climate.

TMTC is also imperfectly substitutable. Because team cohesion has been shown to be an evolving social dynamic that emerges partially as a function of shared experiences, exposure to shared threats, reciprocal self-disclosure, expression of similar values, and cooperation in the pursuit of common goals (Hogg, 1992), it would be practically impossible to provide a perfect substitute for cohesion without creating these same shared experiences over time. In sum, TMTC appears to possess all of the attributes of a strategic asset, and thus, according to the RBV, should be positively related to superior firm performance. Therefore, based both on the logic of the RBV and on prior empirical findings on cohesion and team performance, we predicted that cohesion would be positively related with the performance of the simulated firms used in our current study. Also, given that cohesion-performance relationships are likely to be stronger and more consistent than leadership-performance relationships (that will vary as a function 
of situational factors and other contingencies), we predicted that cohesion would explain more variation in performance than leadership.

Hypothesis 3: Cohesion will be positively associated with the performance of simulated firms.

Hypothesis 4: Cohesion will explain more variation in the performance of simulated firms than will leadership.

\section{Method}

\section{Participants}

Participants were 328 undergraduate management students (202 men, 126 women; 305 native U.S. students, 23 international students) enrolled in nine sections (three fall semester sections and six spring semester sections) of the capstone Strategic Management and Policy course for graduating seniors at a Doctoral/Research Extensive University. We created diverse teams in each section by categorizing individuals in terms of major, gender and nationality and then randomly assigned individuals to teams within each category in a stepwise fashion so that each team included a variety of majors, included no more than one international student, and included both men and women. In short, the process resulted in 81 diverse teams, representing 81 companies. Team size ranged from three to five, with a mean of 4.05. One team did not respond to our leadership questionnaire and was therefore dropped from the study, resulting in 80 teams for this empirical investigation.

\section{Strategic Management Simulation}

Recent years have seen increased use of complex management simulations as an empirical tool, and the paradigm has produced valuable results on a number of issues central to strategic management, organizational theory, and organizational behavior (Chatman \& Barsade, 1995; Chatman et al., 1998; Chesney \& Locke, 1991; Isabella \& Waddock, 1994; Lant \& Mezias, 1990; Waddock \& Isabella, 1989). We chose simulation as our research method because it allowed us to study complex organizational phenomena in a controlled setting in a manner that was involving to participants and that incorporated a host of company and industry factors commonly faced by managers. Our use of a simulation methodology adds breadth to the leadership-cohesion-performance literature, which has relied on other methodological tools to examine this important relationship.

We used Airline, A Strategic Management Simulation (Smith \& Golden, 1994). Airline is a complex, computer-assisted strategic management simulation in which teams function as top management teams of individual airlines that compete against one another in the commuter airline industry. The simulation was designed to model many key attributes of top management decisions and resultant firm outcomes and produce rich financial feedback to participants about 
both their own firm and the industry. The simulation is also rather unique in that the simulation algorithms are based on extensive research of the commuter airline industry, thereby providing as high a level of realism in the market dynamics of the simulation as possible.

Each of the nine sections represented a single industry comprised of 4-12 firms. Although sections varied in the number of competing airlines, all firms within each section had an equal chance to attain profitability because the simulation adjusted the number of available markets to each airline based on the number of firms in the industry. After an initial 75-minute meeting in which individuals were assigned to teams, became acquainted with their teams, and began discussing the simulation, teams then met weekly in separate 75-minute sessions across a twelveweek period to make all strategic and tactical decisions about their business. Each simulation period (i.e., week) represented a calendar quarter for the firm.

Experienced graduate teaching assistants keyed the decision form information into the computer's simulation software each week, which computed a myriad of team and industry information. At the beginning of each simulation period, each team received printouts of their financial statements, operations management statistics, financial statistics, market reports, industry statistics, and so on. Each graduate assistant received formal training on how to run the software and manage the simulation classes to promote consistency in administering this research. The authors also periodically attended each section to be sure that all simulation sections were being run the same way.

Ten percent of each student's grade in the course was based on his or her airline's financial performance relative to competitors. This was determined using a number of financial ratios, including those used to measure the dependent variable used in this study. Each week, every simulation team received a report showing their overall financial performance to date, relative to their competitors. This promoted industry competition and created a shared goal among teams to enhance their airline's performance across the course of the simulation.

\section{Measurement of Superior Performance (SP) of Simulated Firms}

Firm profitability, or financial performance, is the dominant measure of firm performance in strategy research (Venkatraman \& Ramanujan, 1986). Woo and Willard (1983) factor analyzed fourteen quantitative financial and operational measures of performance and found that the profitability factor had the highest factor magnitude and that return on sales (ROS) and return on investment (ROI) loaded highly on that factor. We used relative median return on sales (RMROS) as one measure of superior performance (SP) of simulated firms. RMROS is the differences between the firm's ROS and industry median ROS, indicating whether the firm's ROS was above (superior), at (median), or below (inferior) industry ROS (and to what extent). Each firm can buy or lease airplanes. As a result, common ROI measures, such as return on assets (ROA), are problematic because the cost of leasing planes does not appear on the balance sheet - making ROA difficult to compare across firms. Arguably, two of the largest resources in an airline 
company are its airplanes and employees. As such, we used two common airline profitability measures that are associated with these two resources to measure SP - Relative Median Net Profit Per Seat Mile (RMNPSM) and Relative Median Net Profit Per Employee (RMNPE). A fourth measure of SP, Relative Median Earnings Per Share (RMEPS), was added to determine whether a firm's shareholders were reaping earnings per share better than, worse than, or at the industry median. Thus, for this study, we define superior performance (SP) of simulated firms as performance (on RMROS, RMNPSM, RMNPE, RMEPS) that is above the industry median. Triangulating across multiple measures helps to overcome weaknesses inherent in each measure of SP (Kerlinger, 1986).

At the end of each simulation period, we collected firm and industry financial data and converted them into SP measures: RMROS, RMNPSM, RMNPEE and RMEPS. Then, each SP measure was averaged across 11 simulation periods to represent an overall SP measure over the entire period of the study. Principal Component Analysis (PCA) showed that these four SP measures were highly correlated and loaded onto a single component (see Results). Therefore, we used the PCA score as a single composite measure of SP.

\section{Measurement of Leadership Behaviors}

At the end of the entire simulation, participants completed a questionnaire which asked them to identify who was the leader of their team or who acted most like the leader of their team (in the rare event of a tie, scores on question 1 below were used to identify the leader). Participants were then asked to rate the leader's behaviors using the following questions (each employing a five-point scale with 1 - Strongly Disagree, 2 = Disagree, $3=$ Neither Agree nor Disagree, $4=$ Agree, and $5=$ Strongly Agree).

1. Contributed to the leadership of the firm

2. Kept the team focused on completing its work

3. Helped maintain team harmony and good relationships

4. Proved trustworthy in doing their fair share of the work

5. Was a negative influence on the team (Reverse scored for Principal Component Analysis)

We then averaged the team members' scores for each of the five questions (excluding the leader's scores). Principal Component Analysis (PCA) showed that questions 1,2 and 4 were highly correlated and loaded onto one principal component, which we labeled Leader's Task Behavior, while Questions 3 and 5 were highly correlated and loaded onto another principal component, which we labeled Leader's Relationship Behavior. Though time constraints in administering the questionnaires did not allow us to use longer, previously validated measures such as the Leader Behavior Description Questionnaire (Stogdill \& Coons, 1957), our use of two multi-item scales reffecting Leader's Task Behavior and Relationship Behavior is consistent with the large body of prior work on leadership style that has emphasized task and interpersonal behavior as the two primary dimensions of leadership style (Bass, 1990; Katz \& Kahn, 1978). 


\section{Measurement of Cohesion}

After each of the twelve simulation periods, participants were asked to complete a one-page questionnaire assessing team cohesion. Items were written both to assess cohesion within each simulated firm directly, using our definition of cohesion as member attraction to the team and desire to remain in it, and to assess group processes and member perceptions that have been demonstrated repeatedly in prior research to be strongly associated with cohesion, including good working relationships (Darley, Gross \& Martin, 1951; Seashore, 1954), high contribution levels (Karau \& Williams, 1997), and a shared commitment to completing the group task (Klein \& Mulvey, 1995). These elements are assessed in many widely-used comprehensive group cohesion questionnaires, such as the Group Environment Questionnaire (Carron, Widmeyer \& Brawley, 1985) and the Group Attitude Scale (Evans \& Jarvis, 1986), that were unsuitable for the current research due to their length and the time limitations inherent to our simulation periods. Specifically, the following items were used to assess cohesion and its key elements in a clear, efficient, and face-valid manner were as follows:

1. I enjoyed working with my teammates.

2. I wish I was on a different team. (Reverse scored for Principal Component Analysis)

3. The team worked well together.

4. Everyone contributed to the discussion.

5. The team wasted a lot of time. (Reverse scored for Principal Component Analysis)

6. I trust that my teammates will do their fair share of the work.

Each member responded to these six questions about the cohesion of their simulated firm using the following scale, $1=$ Strongly Disagree, $2=$ Disagree, $3=$ Neither Agree nor Disagree, $4=$ Agree, and $5=$ Strongly Agree. Individual responses for each question were aggregated into a team average, which was then averaged across simulation periods. Principal Component Analysis (PCA) showed that these six questions were highly correlated and loaded onto a single component (see Results). Therefore, they were combined into a single component measure of cohesion.

\section{Control Variables}

Leader's Gender. Since gender has become a more prominent issue in the leadership literature (Bass, Avolio \& Atwater, 1996; Eagly, Karau \& Makhijani, 1995), we controlled for its effect in the statistical models using dummy coding (male leaders $=1$ and female leaders $=2$ ).

Firm Size and Team Size. Firm size can impact performance through economies of scale, monopoly power and bargaining power (Chandler, 1990). In this study, firm size is measured as total airplane seats (in their fleet) to capture both the number and the size of their planes. In addition, because the team size ranged from three to five members depending on enrollment in each section, we included team size (number of team members) as a control variable. 
Leverage. Companies with high debt levels use large portions of their cash flows to service debt obligations, thus reducing free cash flow. A reduction in free cash flow disciplines managers to invest wisely (Jensen, 1986) and to closely monitor business strategy (Hoskisson, Johnson \& Moesel, 1994). Hence, leveraging debt can improve performance unless the firm uses too much debt to fund the firm's assets and is unable to meet its debt obligations. In this study, leverage is measured using the firm's debt to asset ratio.

Competitors. Each section of the course represented one industry. Each industry contained between four and twelve airline companies depending on the number of students in the section. Porter (1980) tells us that the number of competitors in an industry can affect the attractiveness of the industry and thus its profitability, and can impact industry rivalry. Moreover, competitive rivalry might also have psychological effects on teams' strategic decisions. As such, we included a control variable that represented the number of competitors in the industry. Although we partly controlled for industry effects by using firm performance relative to industry median, having the number of competitors in the industry as a control variable could further control for the industry effects on firm performance, which allowed us to better evaluate the relationship between organizational leadership, cohesion, and firm performance.

\section{Statistical Models}

We used correlation and multiple regression to test our hypotheses. Tests across statistical models involved computing and testing the statistical-significance of incremental $R^{2}$ to determine the extent to which key variables stated in the hypotheses explained variation in the dependent variable beyond variables in the control model and other models involved the specific comparative analyses.

\section{Results}

Principal Component Analysis (PCA) was performed to summarize most of the total variance into the minimum number of principal components (Hair, Anderson, Tatham \& Black, 1995). Table 1 shows Barlett's Test of Sphericity (BTS), eigenvalues, total variance explained, and the component loadings of SP (4 measures), Cohesion (6 items) and Leadership Behaviors (5 items). The BTS Chi Square statistics were statistically significant at $p<0.001$ for all three constructs. PCA of four SP measures showed that the first component accounted for $95.88 \%$ of the total variance and was the only principal component with an eigenvalue significantly greater than one. Similarly, PCA of the cohesion questionnaire items showed that all 6 items loaded highly onto one principal component, which had an eigenvalue significantly greater than one and accounted for $82.59 \%$ of the total variance. We found a high degree of internal consistency among these six Cohesion items with a Cronbach's Alpha score of 0.96 . 
Table 1

PCA Analysis of Cohesion, Performance, and Leadership Behaviors

\begin{tabular}{lccc}
\hline & $\begin{array}{c}\text { Cohesion } \\
\text { (6 items) }\end{array}$ & $\begin{array}{c}\text { Superior } \\
\text { Performance } \\
\text { (4 measures) }\end{array}$ & $\begin{array}{c}\text { Leadership } \\
\text { Behaviors } \\
\text { (5 items) }\end{array}$ \\
\hline Factor 1 & all items & all measures & 3 items \\
Loadings (Min-Max): & $0.85-0.98$ & $0.96-0.99$ & $0.80-0.86$ \\
Eigenvalue & 4.95 & 3.84 & 2.67 \\
$\%$ Variance & $82.59 \%$ & $95.88 \%$ & $53.36 \%$ \\
\hline Factor 2 & $\mathrm{N} / \mathrm{A}$ & $\mathrm{N} / \mathrm{A}$ & 2 items \\
Loadings (Min-Max): & $\mathrm{N} / \mathrm{A}$ & $\mathrm{N} / \mathrm{A}$ & $0.83-0.92$ \\
Eigenvalue & 0.39 & 0.11 & 1.10 \\
$\%$ Variance & $5.87 \%$ & $0.75 \%$ & $21.90 \%$ \\
\hline
\end{tabular}

Barlett's Test

$588.31 * * *$

$660.78 * * *$

$126.35^{* * *}$

*** Indicate that the BTS Chi Square statistic was significani at $p<0.001$

PCA of five questionnaire items of leadership behaviors showed that three items (Item \#1, \#2 and \#4) loaded highly onto one principal component (labeled Leader Task Behavior) and two items (Items \#3 and \#5) loaded highly onto a second principal component (labeled Leader Relationship Behavior). Both components had eigenvalues greater than one and collectively accounted for $75.26 \%$ of the total variance. High Cronbach Alpha scores of 0.88 and 0.82 for the Leader Task Behavior items and the Leader Relationship Behavior items, respectively, indicate high internal reliability. The PCA scores for SP, Cohesion, Leader Task Behavior, and Leader Relationship Behavior were later used for correlation and regression analysis.

Correlations and descriptive statistics are summarized in Table 2. Leader Relationship Behavior had a weak correlation with SP $(\mathrm{p}<0.10)$, and Leader Task Behavior had no statistically-significant relationship with SP, providing support for Hypothesis 1. Both Leader Relationship Behavior $(\mathrm{p}<0.01)$ and Leader Task Behavior $(p<0.01)$ had strong positive associations with Cohesion, providing strong support for Hypothesis 2. Cohesion had a highly significant, positive relationship with $\mathrm{SP}(\mathrm{p}<0.01)$, providing strong support for Hypothesis 3 . The control variables Firm Size $(p<0.01)$ and Leverage $(p<0.05)$ were negatively correlated with SP, and Cohesion had a weak, negative association with leader gender $(\mathrm{p}<0.1)$. Some of the control variables had statistically-significant relationships, however the Variance Inflation Factors did not indicate multicollinearity. Other statistical and graphical analyses did not show any violations of the assumptions underlying multiple regression analysis. 
Table 2

Correlations and Descriptive Statistics

\begin{tabular}{|c|c|c|c|c|c|c|c|c|c|c|c|c|}
\hline Variable & Mean & S.D. & 1 & 2 & 3 & 4 & 5 & 6 & 7 & 8 & 9 & 10 \\
\hline 1 Superior Performance & 0.00 & 1.00 & 1.00 & & & & & & & & & \\
\hline 2 Leader Presence & 0.80 & 0.19 & 0.12 & 1.00 & & & & & & & & \\
\hline 3 Leader - Task & 0.00 & 1.00 & 0.08 & 0.07 & 1.00 & & & & & & & \\
\hline 4 Leader - Relation & 0.00 & 1.00 & $0.19 \dagger$ & 0.00 & 0.00 & 1.00 & & & & & & \\
\hline 5 Leader Gender & 1.31 & 0.46 & 0.07 & 0.06 & 0.05 & -0.15 & 1.00 & & & & & \\
\hline 6 Cohesion & 0.00 & 1.00 & $0.30^{* *}$ & 0.08 & $0.32 * *$ & $0.34 * *$ & $-0.22 \dagger$ & 1.00 & & & & \\
\hline 7 Team Size & 4.04 & 0.56 & 0.07 & -0.03 & -0.06 & $-0.28^{*}$ & 0.10 & -0.13 & 1.00 & & & \\
\hline 8 Competitors & 10.38 & 2.90 & -0.12 & -0.05 & 0.02 & -0.13 & -0.05 & -0.18 & $0.54^{* * *}$ & 1.00 & & \\
\hline 9 Firm Size & 91.32 & 30.19 & $-0.42 * * *$ & 0.17 & -0.03 & -0.05 & -0.15 & 0.04 & -0.03 & -0.05 & 1.00 & \\
\hline 10 Leverage & 0.55 & 0.20 & $-0.24 *$ & $-0,03$ & 0.10 & -0.17 & $0.25^{*}$ & -0.01 & 0.09 & 0.08 & 0.11 & 1.00 \\
\hline
\end{tabular}


Tables 3 and 4 show the multiple regressions most central to testing our hypotheses. Table 3 shows those regressions for which Performance is the dependent variable, and Table 4 shows those regressions for which Cohesion is the dependent variable. Hypothesis 1 states that leadership will have no direct relationship with SP. Model 1 in Table 3 tests the direct effects of Leadership Behaviors (Task Behavior and Relationship Behavior) on SP. After controlling for Number of Competitors, Team Size, Firm Size, Leverage, and Leader Gender (the Control Variables), Leader Relationship Behavior was only weakly associated with SP $(\mathrm{p}<0.10)$ and Leader Task Behavior had no significant association with SP, supporting Hypotheses $1 \mathrm{a}$ and $1 \mathrm{~b}$. The incremental $\mathrm{R}^{2}$ for Model 1 is also non-significant, meaning that the Leadership Variables do not significantly explain variation in SP beyond that explained by the control variables, which also supports Hypothesis 1 .

Hypothesis 2 states that Leadership will be positively associated with Cohesion. The Full Model shown in Table 4 tests the direct effects of Leadership Behaviors (Task Behavior and Relationship Behavior) on Cohesion. After controlling for the effects Team Size, Number of Competitors, Firm Size, Leverage, Performance (SP), and Leader Gender (the Control Variables) both Leader Relationship Behavior and Leader Task Behavior have strong, positive, highly significant relationships with Cohesion, with $p$-values of $p<0.001$ and $p<0.05$, respectively, providing strong support for Hypotheses $2 a$ and $2 b$. The $14 \%$ change in $R^{2}$ from adding the Leadership Variables to the Control Model is also highly significant at $\mathrm{p}<0.001$, providing strong support for Hypothesis 2 .

Hypothesis 3 states that Cohesion will be positively associated with SP. Model 2 in Table 3 tests the direct effect of Cohesion on SP. After controlling for the Control Variables, Cohesion has a highly-significant, positive relationship with SP $(p<0.001)$, provide strong support for Hypothesis 3 . The incremental $R^{2}$ for Model 2 is also highly significant ( $\mathrm{p}<0.001$ ), with Cohesion explaining $28 \%$ of the total variation in SP for Model 2 (i.e., the $10 \%$ incremental $\mathrm{R}^{2}$ divided by the total $\mathrm{R}^{2}$ of $36 \%$ for Model 2), which also lends support to Hypothesis 3 .

Hypothesis 4 states that Cohesion will explain more variation in SP than will leadership. In Model 3 in Table 3 (the Full Model), we tested the direct effect of both leadership behaviors and Cohesion on SP. The results indicate that the presence of Cohesion in the Full Model reduced the level of significance of Leader Relationship Behavior from being weakly significant $(p<0.10)$ in Model 1 to being non-significant, and Leader Task Behavior remained statistically non-significant. As in Model 2, Cohesion continued to maintain a strong, highly-significant, positive relationship with SP $(\mathrm{p}<0.01)$ in the Full Model. The mere $1 \%$ change in incremental $\mathrm{R}^{2}$ (from $10 \%$ to $11 \%$ ) going from Model 2 to Model 3 shows that adding the Leadership variables does little to explain any additional variation in SP beyond that already explained by Cohesion. In other words, Cohesion is explaining more variation in SP than both Leadership variables combined, supporting Hypothesis 4. In sum, our statistical results provide strong support for all the hypotheses set forth in this paper. 
Table 3

Results of Multiple Regression Analysis ( $Y=$ Superior Performance)

\begin{tabular}{|c|c|c|c|c|}
\hline \multirow[t]{2}{*}{$\mathbf{Y}=\mathbf{S P}$} & $\begin{array}{c}\text { Control } \\
\text { Model }\end{array}$ & $\begin{array}{c}\text { Model 1: } \\
\text { Controls + } \\
\text { Leadership }\end{array}$ & $\begin{array}{l}\text { Model 2: } \\
\text { Controls + } \\
\text { Cohesion }\end{array}$ & $\begin{array}{l}\text { Model 3: } \\
\text { Full Model }\end{array}$ \\
\hline & Beta $^{\mathfrak{a}}$ & Beta* & Beta & Beta $^{a}$ \\
\hline \multicolumn{5}{|l|}{ Control Variables: } \\
\hline Team Size & 0.20 & $0.26^{*}$ & $0.20 \dagger$ & $0.23 \dagger$ \\
\hline Competitors & $-0.23 \dagger$ & $-0.24^{*}$ & -0.17 & -0.17 \\
\hline Firm Size & $-0.39 * * *$ & $-0.38 * * *$ & $-0.39 * * *$ & $-0.38 * * *$ \\
\hline Leverage & $-0.20 \dagger$ & $-0.19 \dagger$ & $-0.23^{*}$ & $-0.21^{*}$ \\
\hline Leader Gender & 0.03 & 0.05 & 0.11 & 0.12 \\
\hline \multicolumn{5}{|l|}{ Independent Var's: } \\
\hline \multicolumn{2}{|l|}{ Leader Task Behavior } & 0.11 & & 0.00 \\
\hline \multicolumn{2}{|c|}{ Leader Relationship Behavior } & $0.19+$ & & 0.09 \\
\hline Cohesion & & & $0.34 * * *$ & $0.31 * *$ \\
\hline $\mathrm{R}^{2}$ & 0.26 & 0.30 & 0.36 & 0.37 \\
\hline Adjusted $\mathrm{R}^{2}$ & 0.21 & 0.23 & 0.31 & 0.30 \\
\hline F Value & $5.13 * * *$ & $4.38^{* * *}$ & $6.95^{* * *}$ & $5.15 * * *$ \\
\hline Incremental $\mathrm{R}^{2 \mathrm{~h}}$ & & 0.04 & 0.10 & 0.11 \\
\hline Incremental F Value ${ }^{b}$ & & 1.50 & $12.04 * * *$ & $3.91 * *$ \\
\hline
\end{tabular}

* Standardized regression coefficients

b Listed model Versus the Control Model

$\dagger \mathrm{p}<0.10$

* $\mathrm{p}<0.05$

$* * \quad p<0.01$

*** $\mathrm{p}<0.001$ 
Table 4

Results of Multiple Regression Analysis ( $Y=$ Team Cohesion)

\begin{tabular}{lcc}
\hline Y $=$ Team Cohesion & Control Model & Full Model \\
\cline { 2 - 3 } & Beta $^{\mathrm{a}}$ & Beta $^{*}$ \\
\hline Control Variables: & & \\
$\quad$ Team Size & -0.10 & 0.02 \\
Competitors & -0.09 & -0.13 \\
Firm Size & 0.15 & 0.14 \\
Leverage & 0.16 & 0.13 \\
Performance (SP) & $0.42^{* * *}$ & $0.31^{* *}$ \\
$\quad$ Leader Gender & $-0.26^{*}$ & $-0.24^{*}$ \\
\hline Independent Var's: & & $0.30^{* * *}$ \\
$\quad$ Leader Task Behavior & & $0.26^{*}$ \\
$\quad$ Leader Relationship Behavior & & 0.36 \\
\hline $\mathrm{R}^{2}$ & 0.22 & 0.29 \\
Adjusted R & & $4.98^{* * *}$ \\
F Value & 0.15 & 0.14 \\
Incremental R & $3.39^{* *}$ & $16.45^{* * *}$ \\
Incremental F Value & & \\
\hline
\end{tabular}

- Standardized regression coefficients

b Listed model Versus the Control Model

$+\mathrm{p}<0.10$

$* \quad p<0.05$

$* * \quad p<0.01$

$* * * \quad \mathrm{p}<0.001$

\section{Discussion}

Our results support the reasoning that leadership's activation of team cohesion can serve as a strategic asset capable of generating a sustainable competitive advantage and superior performance (SP). Specifically, we found that leadership had no direct relationship with performance. However, it did have a significant, positive relationship with cohesion. In turn, cohesion had a strong, significant, positive relationship with performance. Thus, cohesion was a significant predictor at $\mathrm{p}<.001$ and accounted for a significant percentage of the explained variance in SP. Moreover, cohesion added significant explanatory power over and above a model containing both all control variables and leadership, with 
the incremental $R^{2}$ significant at $p<.01$. Thus, cohesion appears to be strongly linked to performance, and accounts for more variation in performance than does leadership. Further, our full model is potent in that it explains $37 \%$ of the total variance in SP. Taken as a whole, our results suggest that leadership does play a role in enhancing performance, but that this indirect role is to strengthen team cohesion, which has a more direct relationship with performance.

With regard to the RBV (Barney, 1991), our results provide additional evidence that cohesion can serve as an intangible strategic asset capable of creating superior firm performance. The RBV suggests that in order for resources to be a source of sustainable competitive advantage they must be invested in, upgraded, and reconfigured to meet changes in competitive context (Collis \& Montgomery, 1997). Our results suggest that leaders can play a key role in creating competitive advantage by fostering the development of cohesion, which is particularly pertinent in today's competitive landscape where changes in top management team membership are not uncommon due to organizational restructuring, reorganization, mergers, and acquisitions. To our knowledge, the present research is the only empirical attempt to examine the leadership-cohesion-performance relationship from an RBV perspective.

Our results also support the reasoning inherent in many contingency theories that leadership cannot be used to explain team effectiveness without considering the role of additional variables such as task attributes (Hersey \& Blanchard, 1988), follower characteristics (Graen \& Uhl-Bien, 1995), the instrumentality of worker efforts (House, 1971), and group processes (Barrick, Stewart, Neubert \& Mount, 1998; Vroom \& Yetton, 1973). Our results suggest that leaders can behave in ways that optimize key intangible resources within individuals and groups, such as cohesion, that can substantially enhance performance (Dionne, Yammarino, Atwater \& James, 2002; Ensley et al. 2002; Jung \& Sosik, 2002). Although our results clearly support the logic that variables other than leadership can be crucial determinants of performance, they also show that leadership can still play an important role by serving as a lever for enhancing team cohesion. Thus, although it is possible that cohesion could operate as a stand-alone asset, leadership may still be crucial in developing and sustaining cohesion. Thus, leadership could serve as the feedstock of effective group processes, such that over time, team cohesion could well deteriorate in the absence of effective leadership.

With regard to TMTs, our results suggest that leadership may be central to the focus and open communication necessary for making effective strategic decisions conducive to high levels of performance. Thus, if our results replicate in future studies on actual firms, it is possible that CEOs could enhance the profitability of their firms indirectly through the use of leadership activities that may activate interpersonal strategic assets such as cohesion. Specifically, extending prior research on leadership and cohesion to TMT contexts, CEOs may be able to strengthen TMT cohesion via the use of effective task-oriented behaviors such as building commitment to shared goals, coordinating and realigning corporate values, and keeping TMT members focused on tasks with high value and relevance to the 
firm. Similarly, CEOs might also be able to enhance TMT cohesion by using effective relationship behaviors involving coaching and facilitation, impression management, skill development, motivational communication, social support of TMT members, and the development of meaningful, shared social experiences. Although we acknowledge that these conclusions are currently speculative, they do provide fodder for future exploration.

Our research strategy had unique strengths, as well as some limitations that could be addressed in future research. First, our use of a strategic management simulation allowed us to study key variables in a well-controlled fashion in a manner that is not usually possible in work organizations, contributing to internal validity. Yet, external validity is a concern because we studied senior-level business students playing the role of top managers rather than studying TMTs in intact organizations. Our sample was also restricted to a single university, and the simulation was based on only one industry. Nevertheless, our results may still have some implications for practicing organizations despite sample constraints because: (a) The simulation incorporated a host of decision factors that were modeled after actual industry variables and that reflected random change in the competitive environment; (b) Each team functioned as a simulated TMT in terms of planning and implementing all strategic, tactical, and operating elements of their firm; (c) Teams made their own decisions, and resulting firm and industry outcomes were reliant on the interaction of the decision outcomes of multiple firms and industry variables; (d) The simulation was involving to participants, thereby enhancing the likelihood that key processes relevant to organizational settings were indeed activated. Nonetheless, future research that examines these processes in actual organizations would clearly enhance the literature.

Second, our research has taken a crucial step by documenting that leader behaviors are associated with team cohesion, and that cohesion is associated with enhanced performance, suggesting that leadership can affect performance by strengthening cohesion. However, we examined only two aspects of leadership style, and have not isolated the specific mechanisms through which cohesion enhances performance. Future research might seek to identify the exact processes through which leadership style may be linked to enhanced team cohesion and performance, using more extensively-validated and comprehensive measures of leadership behavior and cohesion. Future studies could also seek to employ longer, more extensively-validated measures of leadership style and team cohesion.

Finally, future research could also examine the effects of leadership on other potentially important group processes, such as conflict, coordination, and communication. The influence of other variables, such as team member personality, diversity, or top management team culture could also be examined for its impact on team processes and performance. We hope that the current study is useful in generating additional interest in the impact of leadership on other variables important to team effectiveness and firm performance, as well as in highlighting the usefulness of complex business simulations in studying the RBV and strategic management issues. 


\section{References}

Amit, R., \& Schoemaker, P. J. H. (1993). Strategic assets and organizational rent. Strategic Management Journal, 14, 33-46.

Barney, J. (1991). Firm resources and sustained competitive advantage. Journal of Management, 17, 99-120.

Barney, J. B., \& McEwing, M. D. (1996). Gaining and sustaining competitive advantage. Boston: Addison-Wesley.

Barrick, M. R., Stewart, G. L., Neubert, M. J., \& Mount, M. K. (1998). Relating member ability and personality to work-team processes and team effectiveness. Journal of Applied Psychology, 83, 377-391.

Bass, B. M. (1990). Bass \& Stogdill's handbook of leadership (3rd ed.). New York: Free Press.

Bass, B. M., Avolio, B. J., \& Atwater, L. (1996). The transformational and transactional leadership of men and women. Applied Psychology: An International Review, 45, 5-34.

Bass, B. M., Jung, D. I., Avolio, B. J., \& Berson, Y. (2003). Predicting unit performance by assessing transformational and transactional leadership. Journal of Applied Psychology, 88, 207-218.

Beal, D. J., Cohen, R. R., Burke, M. J., \& McLendon, C. L. (2003). Cohesion and performance in groups: A meta-analytic clarification of construct relations. Journal of Applied Psychology, 88, 989-1004.

Blake, R. R., \& Mouton, J. S. (1985). The managerial grid III: The key to leadership excellence. Houston: Gulf Publishing.

Brewer, M. B., \& Kramer, R. M. (1986). Choice behavior in social dilemmas: Effects of social identity, group size, and decision framing. Journal of Personality and Social Psychology, 50, 543-549.

Carron, A. V., Widmeyer, W. N., \& Brawley, L. R. (1985). The development of an instrument to assess cohesion in sport teams: The group environment questionnaire. Journal of Sport Psychology, 7, 244-266.

Cartwright, D. (1968). The nature of group cohesiveness. In D. Cartwright \& A. Zander (Eds.), Group dynamics: Research and theory (3rd ed., pp. 91-109). New York: Harper \& Row.

Chandler, A.D. 1990. Scale and scope. Cambridge, MA: Harvard University Press.

Channon, D. (1979). Leadership and corporate performance in the service industry. Journal of Management Studies, 16, 185-201. 
Chatman, J. A., \& Barsade, S. G. (1995). Personality, organizational culture, and cooperation: Evidence from a business simulation. Administrative Science Quarterly, 40, 423-443.

Chatman J. A., Polzer J. T., Barsade S. G., \& Neale M. A. (1998). Being different yet feeling similar: The influence of demographic composition and organizational culture on work processes and outcomes. Administrative Science Quarterly, 43, 749-780.

Chesney A. A., \& Locke E. A. (1991). Relationships among goal difficulty, business strategies, and performance on a complex management simulation task. Academy of Management Journal, 34, 400-424.

Collis, D. J., \& Montgomery, C. A. (1997). Corporate strategy: Resources and the scope of the firm. Chicago: Irwin.

Cyert, R. M., \& March, J. G. (1963). A behavioral theory of the firm. Englewood Cliffs, NJ: Prentice-Hall.

Darley, J. G., Gross, N., \& Martin, W. E. (1951). Studies of group behavior: Stability, change, and interrelations of psychometric and sociometric variables. Journal of Abnormal and Social Psychology, 46, 565-576.

Day, D. V., \& Lord, R. G. (1988). Executive leadership and organizational performance: Suggestions for a new theory and methodology. Journal of Management. 14, 453464.

Dierickx, 1., \& Cool, K. (1989). Asset stock accumulation and sustainability of competitive advantage. Management Science, 35, 1504-1511.

Dionne, S. D., Yammarino, F. J., Atwater, L. E. \& James, L. R. (2002). Neutralizing substitutes for leadership theory: Leadership effects and common-source bias. Journal of Applied Psychology, 87, 454-464.

Dyer, W. G. (1977). Team building: Issues and alternatives. Reading, MA: AddisonWesley.

Eagly, A. H., Karau, S. J., \& Makhijani, M. G. (1995). Gender and leader effectiveness: A meta-analysis. Psychological Bulletin, 117, 125-145.

Ensley, M. D., Pearson, A. W., \& Amason, A. C. (2002). Understanding the dynamics of new venture top management teams: Cohesion, conflict, and new venture performance. Journal of Business Venturing, I7, 365-386.

Evans, N. J., \& Jarvis, P. A. (1986). The group attitude scale: A measure of attraction to group. Small Group Behavior, 17, 203-216.

Feldman, D. C. (1984). The development and enforcement of group norms. Academy of Management Review, 9, 47-53. 
Foels, R., Driskell, J. E., Mullen, B., \& Salas, E. (2000). The effects of democratic leadership on group member satisfaction. Small Group Research, 31, 676-701.

Gardner, D.E., Shields, D. L. L., Bredemeier, B.J.L., \& Bostrom, A. (1996). The relationship between perceived coaching behaviors and team cohesion among baseball and softball players. Sport Psychologist, 10, 367-381.

Godfrey, P. C., \& Hill, C. W. L. (1995). The problem with unobservables in strategic management research. Strategic Management Journal, 16, 519-533.

Graen, G. B., \& Uhl-Bien, M. (1995). Development of leader-member exchange (LMX) theory of leadership over 25 years: Applying a multi-level multi-domain perspective. Leadership Quarterly, 6, 219-247.

Guthrie, J. P. \& Hollensbe, E. C. (2004). Group incentives and performance: A study of spontaneous goal setting, goal choice and commitment. Journal of Management, 30 , 263-284.

Hair, J. F., Anderson, R. E., Tatham, R. J., \& Black, W. C. (1995). Multivariate data analysis. Englewood Cliffs, NJ: Prentice Hall.

Hambrick, D. C., \& Mason, P. A. (1984). Upper echelons: The organization as a reflection of its top managers. Academy of Management Review, 9, 193-206.

Hannan, M. T., \& Freeman, J. H. ( 1977). The population ecology of organizations. American Journal of Sociology, 82, 929-964.

Hersey, P., \& Blanchard, K. H. (1988), Management of organizational behavior. Englewood Cliffs, NJ: Prentice-Hall.

Hoegl, M., \& Gemuenden, H. G. (2001). Teamwork quality and the success of innovation projects: A theoretical concept and empirical evidence. Organization Science, $12,435-449$.

Hogg, M. A. (1992). The social psychology of group cohesiveness: From attraction to social identity. New York: New York University Press.

Hogg, M. A., \& Terry, D. J. (2000). Social identify and self-categorization processes in organizational contexts. Academy of Management Review, 25, 121-140.

Hoskisson, R. E., Johnson, R. A., \& Moesel, D. D. (1994). Corporate divestment intensity in restructuring firms: Effects of governance, strategy and performance. Strategic Management Journal, 37, 1207-1251.

House, R. J. (1971). A path-goal theory of leadership effectiveness. Administrative Science Quarterly, 16, 321-338. 
House, R. J., \& Podsakoff, P. M. (1995). Leadership effectiveness: Past perspectives and future directions for research. In J. Greenberg (Ed.), Organizational behavior: The state of the science (pp. 45-82). Hillsdale, NJ: Erlbaum.

Howell, J. M., \& Shamir, B. (2005). The role of followers in the charismatic leadership process: Relationships and their consequences. Academy of Management Review, 30, 96-112.

Hoyt, C., \& Blascovich, J. (2003). Transformational and transactional leadership in virtual and physical environments. Small Group Research, 34, 678-715.

Isabella, L. A., \& Waddock, S. A. (1994). Top management team certainty: Environmental assessments, teamwork and performance implications. Joumal of Management, 20 , 835-858.

Jensen, M. C. (1986). Agency costs of free cash flow, corporate finance, and takeovers. American Economic Review, 76, 323-329.

Jones, G. R., George, J. M., \& Hill, C. W. L. (1998). Contemporary management. New York: McGraw-Hill.

Jung, D. I., \& Avolio, B. J. (1999). Effects of leadership style and followers' culture orientation on performance in group and individual task conditions. Academy of Management Journal, 42, 208-218.

Jung, D. I., \& Sosik, J. (2002). Transformational leadership at work groups: The role of empowerment, cohesiveness, and collective-efficacy on perceived group performance. Small Group Research, 33, 313-336.

Karau, S. J., \& Williams, K. D. (1997). The effects of group cohesiveness on social loafing and social compensation. Group Dynamics: Theory, Research and Practice. 2, 156-168.

Katz, D., \& Kahn, R. L. (1978). The social psychology of organizations (2nd ed.). New York: Wiley.

Kerlinger, F. N. (1986). Foundations of behavioral research (3rd ed.). New York: Holt, Rinehart and Winston.

Khurana, R. (2002). The curse of the superstar CEO. Harvard Business Review; 80, 6067.

Klein, H. J., \& Mulvey, P. W. (1995). Two investigations of the relationships among group goals, goal commitment, cohesion, and performance. Organizational Behavior and Human Decision Processes, 61, 44-53. 
Lant, T. K., \& Mezias, S. J. (1990). Managing discontinuous change: A simulation study of organizational learning and entrepreneurship. Strategic Management Journal, $11,147-179$.

Lieberson, S., \& O'Connor, J. F. (1972). Leadership and organizational performance: A study of large corporations. American Sociological Review, 37, 117-130.

Lott, A. J., \& Lott, B. E. (1961). Group cohesiveness, communication level, and conformity. Journal of Abnormal and Social Psychology; 62, 408-412.

Mauri, A. J., \& Michaels, M. P. (1998). Firm and industry effects within strategic management: An empirical examination. Strategic Management Journal, 19, 211-219.

Michalisin, M.D., Karau, S.J., \& Tangpong, C. (2004). Top management team cohesion and superior industry returns: An empirical study of the resource-based view. Group and Organization Management, 29, 125-140.

Michel, J. G., \& Hambrick, D. C. (1992). Diversification posture and top management team characteristics. Academy of Management Journal, 35, 9-37.

Mullen, B., \& Copper, C. (1994). The relation between group cohesiveness and performance: An integration. Psychological Bulletin, 115, 210-227.

Myers, A. E. (1962). Team competition, success, and the adjustment of group members. Journal of Abnormal and Social Psychologv. 65, 325-332.

Nicholas, J. M., \& Penwell, L. W. (1995). A proposed profile of the effective leader in human spaceflight based on findings from analog environments. Aviation. Space, and Environmental Medicine, 66, 63-72.

Pepitone, A. \& Reichling, G. (1955). Group cohesiveness and the expression of hostility. Human Relations, 8, 327-337.

Pillai, R., \& Williams, E. A. (2004). Transformational leadership, self-efficacy, group cohesiveness, commitment, and performance. Journal of Organizational Change Management, 17, 144-159.

Porter, M. E. (1980). Competitive strategy, New York: Free press.

Pritchard, R. D., Roth, P. L., Jones, S. D., Galgay, P., \& Watson, M. D. (1988). Designing a goal-setting system to enhance performance; A practical guide. Organizational Dynamics, 17, 69-78.

Reed, R., \& DeFillippi, R. J. (1990). Causal ambiguity, barriers to imitation, and sustainable competitive advantage. Academy of Management Review, 15, 88-102. 
Rozell, E. J., \& Gundersen, D. E. (2003). The effects of leader impression management on group perceptions of cohesion, consensus, and communication. Small Group Research, 34, 197-222.

Salancik, G. R., \& Pfeffer, J. (1977). Constraints on administration: The limited influence of mayors on city budgets. Urban Affairs Quarterly, 12, 475-498.

Seashore, S. E. (1954). Group cohesiveness in the industrial work group. Ann Arbor, MI: Institute for Social Research.

Smith, J. R., \& Golden, P. A. (1994). Airline: A strategic management simulation. Englewood Clifts, NJ: Prentice-Hall.

Smith, K. G., Smith, K. A., Olian, J. D., \& Sims, H. P. (1994). Top management team demography and process: The role of social integration and communication. Administrative Science Quarterly, 39, 412-438.

Stogdill, R. M., \& Coons, A. E. (1957). Leader behavior: Its description and measurement. Columbus, $\mathrm{OH}$ : Bureau of Business Research.

Stokes, J. P. (1983). Components of group cohesion: Intermember attraction, instrumental value, and risk tasking. Small Group Behavior, 14, 163-173.

Thomas, A. B. (1988). Does leadership make a difference to organizational performance? Administrative Science Quarterly, 33, 388-400.

Turman, P. D. (2003). Coaches and cohesion: The impact of coaching techniques on team cohesion in the small group sport setting. Journal of Sport Behavior, 26, 86-103.

Venkatraman, N., \& Ramanujan, V. (1986). Measurement of business performance in strategy research: A comparison of approaches. Academy of Management Review, $I I, 801-814$.

Vroom, V. H., \& Yetton, P. W. (1973). Leadership and decision-making. Pittsburgh, PA: University of Pittsburgh Press.

Waddock, S. A., Isabella, L. A. (1989). Strategy, beliefs about the environment, and performance in a banking simulation. Journal of Management, 25, 617-632.

Waldman, D. A., Ramirez, G. G., House, R. J., \& Puranam, P. (2001). Does leadership matter? CEO leadership attributes and profitability under conditions of perceived environmental uncertainty. Academy of Management Journal, 44, 134-143.

Weiner, N., \& Mahoney, T. A. (1981). A model of corporate performance as a function of environmental, organizational, and leadership influences. Academy of Management Journal, 24, 453-470. 
Wernerfelt, B. (1984). The resource-based view of the firm. Strategic Management Journal, $5,171-180$.

Williams, K.D. (2001). Ostracism: The power of silence. New York: Guildford Press.

Woo, C. Y., \& Willard, G. (1983). Performance representation in business policy research: Discussion and recommendation. Paper presented at the annual meeting the Academy of Management, Dallas, TX.

Yalom, 1. D. (1985). The theory and practice of group psychotherapy (3rd ed.). New York: Basic Books.

Yukl, G. (1998). Leadership in organizations (4th ed.). Upper Saddle River, NJ: Prentice Hall.

Michael D. Michalisin is Associate Professor of Management at Southern I1linois University at Carbondale where he teaches strategic management courses. He received his Ph.D. in strategic management and macro-organizational theory from Kent State University. His research interests include the Resource Based View of the Firm, the Natural-Resource-Based View of the Firm, supply chain management, strategic leadership, top management team dynamics, and the validity of annual reports.

Steven J. Karau is Associate Professor of Management at Southern Illinois University at Carbondale where he teaches organizational behavior, human resource, and methodology courses. He received his Ph.D. in social psychology from Purdue University. His research focuses on interpersonal influence processes in social and organizational contexts, including individual motivation within groups, effects of temporal and situational factors on group performance, gender differences in leadership, and ethical perceptions of organizational change processes.

Charnchai Tangpong is Assistant Professor of Management at the College of Business, North Dakota State University where he teaches strategy and organization management courses. He received his Ph.D. in Business Administration from Southern Illinois University at Carbondale. His current research interests include strategic values of firm-supplier relationships, corporate strategy, dynamic capabilities and innovativeness in stakeholder networks. 